\title{
Are Investments in Sustainable Transportation in Tourism Sector Economically Justified
}

\author{
Slađana Lazarević, Jelena Janjušević \\ United Nations Development Program, Podgorica, Montenegro
}

\begin{abstract}
The aim of this paper is to analyze the investments and instruments to be implemented in sustainable transportation in tourism sector to lead to economically efficient urban development. As second biggest energy consumers in the cities, the transport sector ecologically and economically could be main driver leading the low carbon urban development. One of the instruments which could lead economic development through "decarbonization" of urban development is the Sustainable Urban Mobility Plans. An example is the pilot area for four touristic cities where we show how different investments in sustainable transportation in tourism sector can directly contribute to economically justified low carbon development. In this paper, we are referring to the project implemented by UNDP (United Nations Development Program) in Montenegro-Towards Carbon Neutral Tourism within which the Polycentric Sustainable Urban Mobility Plan was developed for the first time for Montenegro. Within the framework of this project, it was considered of great significance to focus on the area of Boka Bay and the Old Royal Capital of Cetinje, which consists of one of the greatest touristic attractions of Montenegro. Considering the fact that second biggest energy consumers in the cities are identified in the transport sector which certainly represents one of the largest polluters in the urban spaces, we are rethinking how sustainable transportation in tourism sector could lead low carbon development of the cities. Investing in the sustainable transportation is not just efficient way of transforming touristic cities in low carbon developed places, but also economically fully justified, and will lead to overall sustainable economic development.
\end{abstract}

Keywords: sustainable transport, economic benefits, investments, tourism development, low carbon development

The current way of life in cities, especially the ways of division of labor and functions, land use, transport, industrial production, agriculture, consumption, recreational activities, and our standard of living, seems responsible for many environmental problems facing humanity. It is clear that people who live in the present, and especially future generations, cannot achieve level of consumption of resources that exist in the industrialized countries, and that doing so does not destroy natural resources. Therefore, towns and cities are key actors in the process of changing lifestyles, production, consumption, and usage patterns of space at economically justified way in order to achieve sustainability. The idea of sustainable development helps us to

Corresponding author: Slađana Lazarević, MSc, architect, United Nations Development Program, Podgorica, Montenegro; research fields: sustainable urban mobility, urban \& spatial planning, energy efficient architecture, energy and transport management, low carbon development, green economy, research in urban planning and architecture, sustainable and carbon neutral tourism, energy rehabilitation of cultural heritage.

Jelena Janjušević, Ph.D., economist, United Nations Development Program, Podgorica, Montenegro; research fields: sustainable and carbon neutral tourism, sustainable development, green economy, corporate finance, financial investment, econometrics in finance, research in finance, microeconomics, macro-economy. 
base our standards of living on the capacity of nature at efficient and effective way.

Low carbon sustainable development leads to the reduction of emissions of greenhouse gases (GHG). Low carbon urban development creates sustainable urban energy structures through integrated planning at all levels with the aim to mitigate climate change. Considering the fact that second biggest energy consumers in the cities are identified in the transport sector which certainly represents one of the largest polluters in the urban spaces, we are asking how transport could lead low carbon and carbon neutral urban development.

Studies indicate that economies that promote sustainable transport are at significant fiscal advantage over those that favor private vehicles use. Many health benefits for the citizens are evident. However, benefits go far beyond better health. Property value in towns and cities with good cycling facilities and efficient public transport leads to being higher, while children who walk or cycle to school perform better in class. Private sector benefits are also evident-reports showed an increase in trading of up to $40 \%$ in areas where walking and cycling became the norm.

\section{Sustainable Urban Mobility Plans ${ }^{1}$ Are Economically Justified}

Sustainable Urban Mobility Plans (SUMP) are strategic plans built on existing practice in planning and considering integral, participatory, and evaluation principles to satisfy the needs of urban residents for mobility and ensure a better quality of life in cities and their surroundings. Such kind of plans are usually made in urban areas and communities characterized by monocentric, where the concentration of human activities in one area is evident. Polycentric Sustainable Urban Mobility Plans (Poly-SUMP ${ }^{2}$ ) are made with the same goals, but unlike SUMP, for those areas that are characterized by dispersed distribution activities, i.e. for the areas (regions) with several urban centers, which have between 5,000 and 200,000 inhabitants ${ }^{3}$.

In this paper, we are referring to the project implemented by UNDP (United Nations Development Program) in Montenegro-Towards Carbon Neutral Tourism within which Poly-SUMP were developed for the first time for Montenegro. Within the framework of the project, it was considered of great significance to focus on the area of Boka Bay and the Old Royal Capital of Cetinje, which consists of one of the greatest touristic attractions of Montenegro.

The examined area comprises of the four coastal municipalities-Herceg Novi, Tivat, and Kotor, as well as the Old Royal Capital of Cetinje. The main objective is to develop, in collaboration with the four involved municipalities, a Polycentric Sustainable Urban Mobility Plan (Poly-SUMP) for the region that will focus on promoting sustainable urban transport solutions and improve the quality of life for both permanent residents, as well as the tourists visiting the area. The Poly-SUMP will be the core document that sets out the way in which the beneficiaries' plans, priorities, and programmes for transforming the transport system will deliver change over time and across a range of different policy objectives. Using creative thinking, pooling resources and the best use of innovation and technology can generate the capacity to continue to make more progress in addressing all the issues and impacts that transport can create, primarily on reducing GHG emissions.

\footnotetext{
${ }^{1}$ Sustainable Urban Mobility Plan—European Platform on Sustainable Urban Mobility Plan—ELTIS, retrieved from www.eltis. org/mobility-plans.

2 Poly-SUMP je Polycentric Sustainable Urban Mobility Plan-Planning Sustainable Mobility Together, retrieved from http://www.poly-sump.eu/.

${ }_{3}^{3}$ Polycentric Sustainable Urban Mobility Plan for Boka Bay and Cetinje 2016-2020, Centre for Sustainable Development, 2016.
} 


\section{Low Carbon Tourism and Urban Mobility}

Researching of the world examples of cities and countries that use renewable sources, came across the most diverse examples of urban planning in order to preserve and improve the environment, where city-states, examples of good planning and design, use only certain renewable energy sources and ways of solving local environmental problems in order to preserve the globe.

Town or city, is the largest unit capable to start addressing many urban architectural, social, economic, and political imbalances, and imbalances of natural resources and the environment that threaten our modern world, and at the same time, the smallest meaningful framework for problem solving. As each city is different, they must find their own ways to achieve sustainability.

While we consider as the biggest energy consumers in the cities, especially those with tourism expansion, existing buildings, we make direct interrelation of energy renovated buildings with sustainable transport options, which lead to low carbon tourism. The reason is simple: When we are coming to the integrated urban planning in the tourism and transport sector, we are facing with huge energy consumption and emissions of GHG just because a sustainable urban mobility lacks in touristic cities. Working on Poly-SUMP for four Montenegrin' cities, we are challenging on the one side with the integration of innovative modern technologies and respecting of the UNESCO protected city area, and on the other side with everyday needs of inhabitants and tourists. Through developing this Polycentric Plan for pilot area for four touristic cities, we are showing how integrated urban planning can directly contribute to low carbon urban development.

The human impact on the environment can be positive or negative, depending on the knowledge and taking into account the climatic and other changes that are directly affected by its operations.

When constructing a building or urban structure, first relevant energy decision is a choice location. In current practice, the choice of location of energy consumption in addition to economic factors and the availability of land does not occupy an important position. Urban mobility in touristic places is of significant importance for leading to the low carbon urban development. In the past, it was not considering interdisciplinary. Today, the issues of energy saving and energy efficiency are paid more attention. The reason for this is their impact on global climate change and air pollution.

One of the most important characteristics of the location is its climate. The location has its own so-called microclimate, which is characterized by local air departure from the regional climate.

Urban morphology is today the poorest and the most rudimental part of urban practices. Although there was much talk and still thinks that they are mainly interested in the urban form of the city, a sort of l'art pour l'artistic determinism, facts and results speak vice versa. (Radović, 2005, p. 41)

In contrast, studies have shown that urban planners are interested in the external manifestations of mutual effects caused by environmental image.

Urban planning, spatial arrangement of objects, their orientation, transportation corridor, interconnection developed and undeveloped, are subordinated to the principles of bioclimatic design and therefore the design of sustainable human spatial planning.

New features and new programs resulting from the application of sustainable spatial planning, urban development as a great challenge, require integration into the existing program content, interconnection, and adequate adjustment to the natural environment, while maintaining the microclimate of the area and integrating all elements of structure in the urban unity of the city as a whole, therefore, key moment of adaptation and 
adjustment of potential new program contents spatial characteristics.

Poly-SUMP will be the key document that defines the way in which the plans, priorities, and programs of the user, concerning the transformation of the transport system, lead to changes over time and affect a number of different policy objectives. It is a way of creative urban thinking and the best use of innovation and technology. Poly-SUMP will make it easier to reach a transportation system accessible to all, connecting communities by improving access to jobs and services, offering access to all residents and visitors, and making the main touristic locations accessible by sustainable urban mobility transport. On the one side, plan will contribute to improving the attractiveness and quality of the urban environment in local centers and key transport corridors, and on the other side, it will decrease energy consumption and reduce GHG emissions, with emphases at tourism sector.

Low carbon sustainable development leads to the reduction of emissions of GHG, while a low carbon spatial development creates sustainable urban energy structure through integrated planning at all levels with the aims to mitigate climate change.

\section{Social and Economic Effects of Investments in Sustainable Transportation}

Stressing the importance of socio-economic aspects in spatial plan, Radović (2005) pointed out:

In the tie line of gathering the cities and the water is a gigantic effect of socialization in the cities. From transport and catering to leisure and a sense of belonging all takes place on the urban coasts and in the water.

And then, we are coming to the transport issues and transport infrastructure in spatial planning. We are coming to the need to reduce $\mathrm{CO}_{2}$ emissions in order to have healthier cities. How can we achieve the low carbon urban development using advantage and disadvantage of tourism expansion in the cities?

Formulating a system framework for low carbon economic development, as well as demanding process for the state administration, the businesses and communities are necessary aspects of a detailed study and research in order to achieve sustainable urban development. Low carbon sustainable development can be seen as a market opportunity at different levels: Through strategic marketing, it can lead to better positioning of the country; through authentic experiences, it can encourage the creation of new environmentally friendly products and services with low $\mathrm{CO}_{2}$; while crossing the low carbon way, business enterprises can help to increase profitability through better environmental practices. Therefore, the reduction in $\mathrm{CO}_{2}$ emissions is seen as a direct indicator of low carbon sustainable spatial development that will affect the mitigation of climate change, not only at the level of policy but in reality.

Observed at the micro level, the emphasis is placed on the built environment that directly contributes to reducing GHG emissions, it will therefore occupy a special place for facilities that use renewable energy (solar, wind, water, and biomass) to generate electricity, and reduce the consumption of the same, which opens the way to organic sustainable building, humane urban environments, creating a favorable microclimate and microenvironments and functioning of this space as a self-sustaining organism created by the principle of low carbon spatial development in terms of economic viability.

So low carbon sustainable development should be seen as a major opportunity, focusing on the interdependence of business and environmental objectives, their mutual profits and positive impact on economy, ecology, and society. This business in tourism can make strong economies of the cities.

\section{The Economic Benefits of Sustainable Urban Mobility Measures and Investments}

Literature, but also experience demonstrates that sustainable urban mobility interventions and investments, 
for example, supporting higher levels of cycling and public transport, are as effective as "traditional" infrastructure projects, which are typically adding new road capacity in or around cities. This is of considerable significance in the EU-wide debate within cities and regions on sustainability, transport, and economic development.

European Commission financed project "EVIDENCE", in report developed under the project describing economic benefits from implementation of the sustainable urban mobility plans, reveals that shifting patterns of spending and project selection away from new high-capacity roads or intercity high-speed rail links have the potential to congestion and pollution and create highly attractive living environments that are increasingly factored into global decisions about inward investment, corporate relocation, and the attraction and retention of highly qualified staff (Wuppertal Institute for Climate, Environment and Energy in Cooperation With Contemporary Transport, Erasmus University Rotterdam, TAEM Urbanistai, University of the West of England, Urban Planning Institute of the Republic of Slovenia, 2014). A city that can reduce the number of vehicles on urban highways and provide high-quality walking and cycling facilities set in an attractive public realm will be more successful than a city characterized by high levels of vehicle traffic, congested roads, and air pollution serious enough to be responsible for mortality and hospitalization on a large scale.

When calculating economic benefits from SUMP, traditional cost benefit analysis (CBA) can be used, however, the CBA methodology is widely criticized in the transport literature for the way it skews decisions in the direction of projects such as additional road capacity, when a wider analysis of costs and benefits would produce a more balanced approach, meaning that it should be widened to include values for the health benefits and reduce the importance of time savings in calculations. It is likely that such an approach would result in more funding for traffic reduction and decarbonized road transport.

Sustainable urban mobility has huge potentials to improve health, reduce carbon, protect nature and ecology, improve international competitiveness, and get better value for money from scarce public funds.

Due to pressing environmental and social concerns, the transport sector is being pushed to consider a wide and growing range of policy objectives alongside the economic ones.

Financial gains. Individuals can achieve major financial benefits through smart and sustainable mobility behavior. Owning a private car is a considerable expenditure for any household. The cost of car ownership begins with the purchase price, followed by the cost of insurance, and a parking space or garage rental. Additional costs are incurred for actually driving a car, which includes fuel costs and maintenance costs, as well as parking costs when away from home. Driving costs can increase by an average of $50 \%$ in cases where congestion is serious.

In addition, external costs created through pollutants and noise emissions, public space consumption, or even accidents are not visible on the drivers' bill. Simple car cost calculators are available online and allow the user to make personalized assessments, taking different parameters into account. A Belgian study commissioned by the regional government of Brussels in 2012 found that the average Brussels inhabitant replacing a car with a bicycle would save $€ 2,853$ each year! This finding includes costs such as maintenance, taxes, and fuel but even excludes purchase costs (Mourey \& Köhler, 2016). In 2008, American transportation departments spent $\$ 63.2$ billion on constructing and maintaining highways. This number could be much lower if people used mass transit, car pools, walking, and cycling to get around.

${ }^{4}$ The economic benefits of sustainable urban mobility measures, report, EVIDENCE project, 2016. 
Other economic benefits. Every trip that involves walking or other active modes - even just strolling down to the bus stop - increases that day's amount of physical activity. Physical exercise is a major factor for people's well-being and walking or using a bicycle is an easy and non-time-consuming way to meet the recommendation of the World Health Organization for a minimum of 150 minutes of physical activity per week. The EU co-funded project SWITCH looked at replacing short car trips with active transport modes and found that regular physical activity increases the life expectancy of women and men by an average of 1.5 and 1.4 years respectively (Mourey \& Köhler, 2016).

Active and sustainable transportation enhances physical, mental, and emotional health. These facets of our lives are interconnected and significantly affect our well-being. Additionally, active and sustainable transportation makes our community safer by reducing the risk of vehicle-pedestrian accidents and keeps our air clean by improving air quality and reducing GHG emissions.

One way that sustainable transportation helps individuals is by making them healthier, and not just in the "less carbon dioxide in the atmosphere" kind of way. Walking and cycling are types of transportation that fall under this umbrella. A person using these modes of transport not only gets exercise, but is immune from the stress of gridlock traffic and having to pay attention to the cars around them. Cycling and walking have no effect on the environment, so they are great modes of sustainable transport.

Congestion costs valuable time and is an economic loss. According to the INRIX National Traffic Scorecard Annual Report, the average car driver in Belgium lost 51 hours in traffic jams in 2014. The time lost in congestion amounts to 96 hours for the average car driver in London the same year, making London Europe's most congested city. Better transport choices can help save time, which can be spent in more enjoyable or productive ways e.g. physical activity, reading, or social interaction (Mourey \& Köhler, 2016).

Congestion also has a specific financial cost through increasing fuel consumption. A study carried out by the Institute for Transport \& Economics of the Technical University of Dresden found that fuel consumption rises by an average of $80 \%$ during periods of urban congestion (Mourey \& Köhler, 2016).

A study led by the French Cyclists' Federation (Fubicy) and French National Centre for Scientific Research (CNRS) with the support of the French government found that car drivers and passengers spend less money than travellers using other modes, contradicting the common fear from business-owners that emphasising walking and cycling more than car-driving will lead to a decrease in revenue. In fact, the study found that car drivers spend the least of any group $-53.7 \%$ of the amount spent by pedestrians, while cyclists and public transport users spend $60.4 \%$ and $55.5 \%$ respectively, again compared to pedestrians.

The European Cyclists' Federation (ECF) estimates that cyclists contribute $€ 111$ billion to economic activity every year in city center and local shops in the European Union. Although pedestrians, cyclists, and public transport users spend less money per visit than drivers, these groups prove to be more loyal to their local shops and visit them two times, 1.3 times, and 1.2 times per week respectively on average, while an average driver visits their local shops 0.7 time per week on average.

\section{Development of New Markets}

More sustainable urban freight solutions have great potential to benefit society in terms of congestion, energy use, air and noise pollution, quality of life, and sustainability, as the movement of goods accounts for approximately $25 \%$ of urban transport-related $\mathrm{CO}_{2}$ emissions and $30 \%$ to $50 \%$ of other pollutants such as particulate matter (PM) and Nitrogen Oxide (NOx). Dutch removals company Aad de Wit has demonstrated 
that introducing a fleet of electric vehicles in a similar company is economically viable. Research from Vrije Universiteit Brussel and the experience of the Cycle Logistics Project suggests that between 50\% and 70\% of goods movements in European cities, they could be shifted to (cargo) bikes (Mourey \& Köhler, 2016).

Coming back to the results of the EVIDENCE project, considering both quality and quantity, for sustainable transportation measures, there was strong evidence of economic benefits: (1) cycling (infrastructure); (2) new public transport systems; (3) enhancements to public transport systems; (4) parking management; (5) cleaner vehicles; (6) site-based travel plans; and (7) personalized travel planning. In addition, the evidence on environmental zones was limited but strong.

Of course, there are certain barriers that are evidenced for development and implementation of sustainable transportation modes: insufficient knowledge; uncertainties about how to conduct pre-implementation appraisals and post-implementation evaluations of SUMP; and concerns that the experiences of successful implementation elsewhere might not be relevant to any local tradition of mobility management.

\section{Mobility Challenge for Cities}

Achieving a healthy, sustainable city requires local air quality and noise to be brought within acceptable limits, whilst also responding to wider environmental concerns; and supporting European climate change targets.

At present, emissions from the transport sector are $22 \%$ of worldwide carbon emissions, but $30 \%$ rising in OECD (Organization for Economic Cooperation and Development) countries (Shergold \& Parkhurst, 2016). As a consequence, it is highly likely that the transport sector will fail to meet its $60 \%$ Europe-wide carbon reduction target (Bows \& Anderson, 2007, pp. 103-110).

An understanding of the potential costs and benefits expected to arise from different transport and mobility investment options is recognized as being an important factor for those making decisions about public spending on mobility infrastructure and services in urban areas.

It was possible to provide an indication of which measures might provide specifically economic benefits, and some approximation of how important these benefits might be. These estimations are presented in Table 1 below.

Table 1

Extent of Economic Benefits of SUMP

\begin{tabular}{|c|c|c|}
\hline Theme & Measures & Strength of economic benefit \\
\hline Clean vehicles and fuels & $\begin{array}{l}\text { Electric battery and fuel cell vehicles } \\
\text { Cleaner vehicles }\end{array}$ & $\begin{array}{l}+ \\
+++\end{array}$ \\
\hline Urban freight & Urban freight & +++ \\
\hline Demand management strategies & \begin{tabular}{|l} 
Access restrictions \\
Road space reallocation \\
Environmental zones \\
Congestion charges \\
Parking
\end{tabular} & $\begin{array}{l}+++ \\
++ \\
++ \\
++ \\
+++\end{array}$ \\
\hline Mobility management & $\begin{array}{l}\text { Site-based travel plans } \\
\text { Personalized travel planning } \\
\text { Marketing and rewarding }\end{array}$ & $\begin{array}{l}++ \\
++ \\
+ \\
\end{array}$ \\
\hline Collective passenger transport & $\begin{array}{l}\text { Public transport enhancements } \\
\text { New public transport systems } \\
\text { Integration of modes }\end{array}$ & $\begin{array}{l}+++ \\
++++ \\
+ \\
\end{array}$ \\
\hline Transport Telematics & $\begin{array}{l}\text { E-ticketing } \\
\text { Traffic management } \\
\text { Travel information }\end{array}$ & $\begin{array}{l}++ \\
+++ \\
+\end{array}$ \\
\hline
\end{tabular}




\begin{tabular}{|l|l|l|}
\hline \multirow{2}{*}{ Less car dependent mobility options } & New models of car use & ++ \\
& Walking & ++ \\
Cycling & +++ \\
& Bike sharing & + \\
& Inclusive urban design & ++ \\
\hline
\end{tabular}

\begin{tabular}{|l|l|l|l|l|}
\hline Key: & $\begin{array}{l}++++ \\
\text { Evidence of more } \\
\text { substantial economic } \\
\text { benefits }\end{array}$ & $\begin{array}{l}+++ \\
\text { Evidence of stronger } \\
\text { economic benefits }\end{array}$ & $\begin{array}{l}++ \\
\text { Economic benefits } \\
\text { clearly seen }\end{array}$ & $\begin{array}{l}+ \\
\text { Some economic } \\
\text { benefits identified }\end{array}$ \\
\hline
\end{tabular}

Note. Source: The economic benefits of sustainable urban mobility measures, report, EVIDENCE project, 2016.

There are also some general time-scales over which a city might see economic benefits emerging from individual interventions. These benefits relate not just to the specific payback of the costs of implementation, but also to how they might contribute to wider-scale changes in a city, from which additional economic benefit will flow. Two specific areas where improvements might be seen are in respect of congestion and air quality. Additionally, it is important to stress direct and indirect effects of travel choices on health (due to pollution and fitness) and the economic costs of these in terms of expenditure on treatment of illness, absenteeism at work, labor turnover, stress, and life expectancy; effects of attractive environments for work and shopping on labor catchment areas, footfall, retail turnover, and property values for housing, workplaces, and retail.

\section{Case Study-Solar Catamarans in Montenegro}

Electric boats are not new, but solar systems represent an interesting development. The vessel's solar generator allows independence from the connection to the electrical power systems. Solar systems are safe and self-sufficient energy sources. Drive system without exhausting gas not only protects the environment but also raises the level of enjoyment in navigation. Electric drives are very effective. Torque is present at all speeds so that the propellers of large diameter can be driven slowly. Because of this, there is no vibration, noise, and unpleasant smell from the engine, so one can breathe freely, enjoying the conversation and navigation. These boats are made for enjoyment, taking into consideration both efficient and economic aspects.

Sustainable modes of transport mentioned are promoted and encouraged in the project "Towards Carbon Neutral Tourism", implemented by UNDP Office in Montenegro and funded by the Global Environment Fund (GEF). The following are the characteristics of one suggested means of such transport.

The Monte Marine Yachting company together with the Municipality of Kotor, recognized the need for the use of solar energy in order to preserve the environment, increase the level of enjoyment of the clients, and reduce costs of maintenance of boats. Solar energy is used on their electric boats for an additional battery charging. Adding solar panels to the electric motor system (battery, charger, and electric motor) leads to unlimited range for their ships. The batteries themselves (without solar panels) have 10 to 12 hours of autonomy. The batteries can be recharged at a conventional electrical network and the price for full recharge is about two dollars. This represents a highly efficient and extremely durable alternative to using fossil fuels. There are no losses on the propeller shafting because the electrical motor is directly connected to the propeller. Our electric boats efficiently solve the problem of protecting the environment and increasing prices of oil derivatives. Ecologically speaking, there has never been a better time to use electric power.

The boat named "Kotor" is an electric passenger catamaran (see Figure 1). It is used at tourist sites, as well as the ferry, etc. The boat can sail for 8-10 hours a day (without solar panels) and allow navigation in total silence. Range of this boat, with installed solar panels, is almost unlimited. Solar panels use light energy from 
the sun, convert it into electricity, and store it in batteries. It is a non-polluting, silent ship that protects the environment, which is also stable, reliable, and easy to maintain and use. It sails on all waterways (rivers, canals, lakes, etc.). Thanks to its two hulls, it is very stable. It is designed and built to be easy to maneuver at a speed of seven knots, being the most efficient at that exact speed. When it sails, "Kotor" makes no bow waves and minimum amount of side waves, because of its elegant waterline similar to sails making the minimum possible resistance. "Kotor" can carry 50 passengers who will appreciate the open view from a deck with glass walls and a remarkable silence on the stern.

When the existing and projected examples of solar vessels are compared to conventional diesel-powered ships, their maximum speed is usually lower, but their average speed on most inland waters are very similar because of the speed limits on small lakes, rivers, and canals. It may be surprising to some that the maintenance of solar boats is equally or even less expensive. The big difference, of course, is that conventional vessels cause a lot of pollution and waves, produce $\mathrm{CO}_{2}$, and consume the oil, which also applies to electric boats that are indirectly powered via the fossil fuels engines. Solar boats, after their production, use fewer resources and can actually produce more energy than they consume, if connected to the network when not sailing. As the sunlight is more predictable than the wind in many areas, and since it can be stored using electrochemical means (batteries and hydrogen), solar boats can really become the main means of transport in certain areas.

Economic analysis of investment in solar catamarans shows a high profitability when calculating through estimated revenues as well as the rate of return on investment. In addition, bearing in mind that this type of maritime transport could link two more towns-Tivat and Herceg Novi, each of them would have a direct economic benefit. Bearing in mind that we are talking about a tourist area with a large number of tourists visiting the Bay of Kotor during the summer season, the analysis carried out within the project shows that the investment return would happen after only three years. The coefficient of relative efficiency of the project, as a measure of profitability of the investment, shows how many units of the net present value returns on each unit of invested funds during the period of exploitation of the investment, and it is 1.65 .

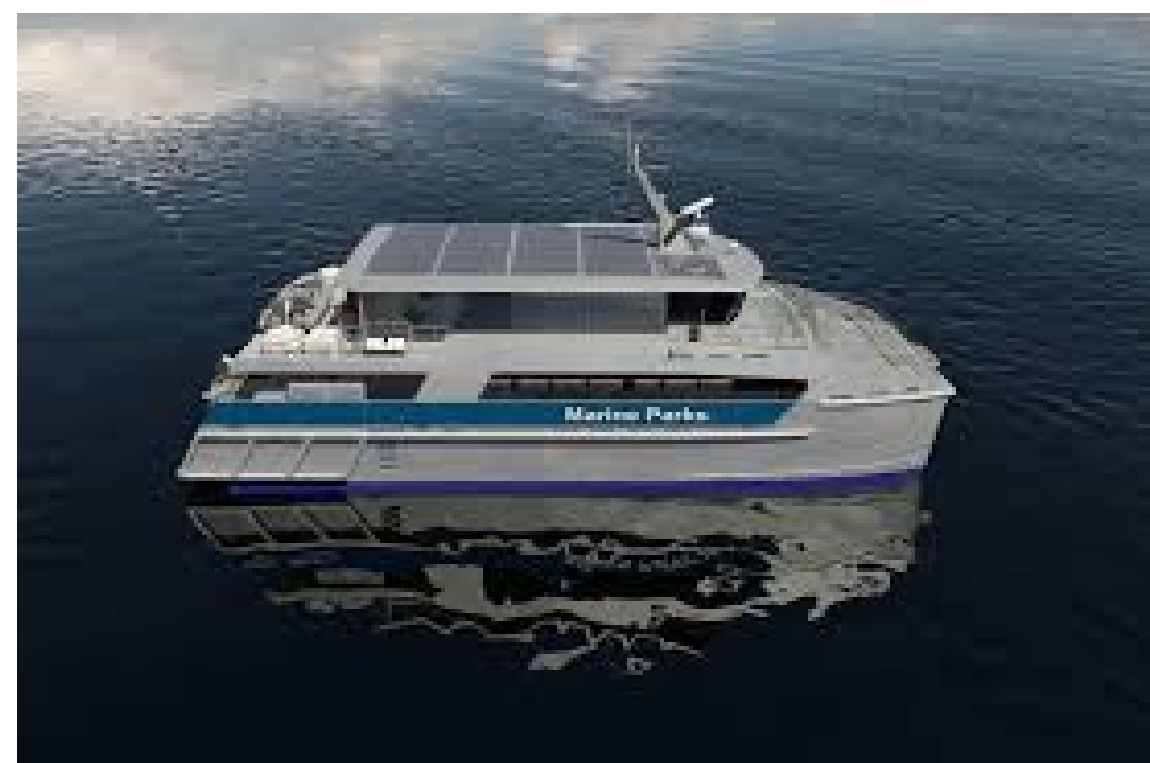

Figure 1. Solar catamaran in Boka Bay. Source: Feasibility study for development of the sustainable, maritime, and public transport with solar catamarans in Boka Bay of Montenegro, 2012. 


\section{Conclusions}

The continuation of the started research work will be reflected in the implementation of the varying measures for improvement of sustainability of the transportation system of these four touristic cities which directly influence in achieving economical benefits. Measures which have to be tested until 2020 are mostly connected with improvement of non-motorized existing and constructing of the new corridors and increasing usage of renewable resources for motorized transport. Measures of emissions of $\mathrm{CO}_{2}$ will be done through development of the first energy management system for transport for Boka Bay and Cetinje which will make the best use of economic benefits of investments in sustainable transportation.

By implementing defined projects, we will contribute to following: ensuring healthy lives and promoting well-being for all at all ages; accessing to affordable, reliable, sustainable, and modern energy for all; building resilient infrastructure; promoting inclusive and sustainable industrialization and fostering innovation; making cities and human settlements inclusive, safe, resilient, and sustainable; and taking urgent action to combat climate change and its impacts by reducing carbon emissions and increasing economic benefits for this pilot area.

\section{References}

Berg Insight. (2015). ITS in public transport. Retrieved from www.berginsight.com/ReportPDF/ProductSheet/bi-its4-ps.pd

Bows, A., \& Anderson, K. L. (2007). Transport policy. Volume 14, issue 2, March 2007, pp 103-110. Retrieved from http://dx. doi.org/10.1016/j.tranpol.2006.10.002

Campbell, R., \& Wittgens, M. (2014). The business case for active transportation: The economic benefits of walking and cycling.

Castex, J., Depaule, J., \& Panerai, P. (2003). Urbane forme (Urban forms). Beograd: Građevinska knjiga.

Cullen, G. (2001). Gradski pejzaž (Urban landscape). Beograd: Građevinska knjiga.

Directive 2010/31/EU of the European Parliament and of the Council on the energy performance of buildings. (2003). Official Journal/L 001.

Elin, N. (2002). Postmoderni urbanizam —dopunjeno izdanje (Postmodern urbanism-Updated edition). Beograd: Orion Art.

Emeli, A., \& Ljungberg, C. (2014). Polycentric sustainable urban mobility plan, grant agreement no. IEE/11/057/SI2.615924, the Poly-SUMP methodology: How to develop a sustainable urban mobility plan for a polycentric region. Retrieved from http://www.poly-sump.eu/

European Commission. (2013). Guidelines-Developing and implementing a sustainable urban mobility plan. Retrieved from http://www.eltis.org/mobility-plans

Expeditio, Kotor, Blue Coach, Podgorica. (2012). Feasibility study for development of the sustainable, maritime and public transport with solar catamarans in Boka Bay of Montenegro. BAS Programme of the European Bank for Reconstruction and Development (EBRD).

Frampton, K. (1983). Towards a critical regionalism: Six points for an architecture of resistance. In H. Foster (Ed.), The anti-aesthetic: Essays on post-modern culture (p. 17). Port Townsend, Washington: Bay Press.

Gidion, S. (2002). Prostor, vreme, arhitektura (Space, time and architecture). Beograd: Građevinska knjiga.

Linč, K. (1974). Slika jednog grada (The image of the city). Beograd: Građevinska knjiga.

Ministry of Sustainable Development and Tourism, Montenegro. (2015). The spatial plan for spatial purpose of the coastal area. Str. 137.

Mourey, T., \& Köhler, D. (2016). Thematic guidelines 2016, European mobility week. Retrieved from https://www.portugal2020. pt/Portal2020/Media/Default/Docs/NOTICIAS2020/Thematic_Guidelines_2016.pdf

Pucar, M. (2006). Bioklimatska arhitektura, Institut za arhitekturu i urbanizam Srbije (Bioclimatic architecture—Glazed spaces and passive solar systems). Beograd: Institute for Architecture and Urban \& Spatial Planning of Serbia.

Pucar, M., Pajević, M., \& Jovanović-Popović, M. (1994). Bioklimatsko planiranje i projektovanje-urbanistički parametri (The bioclimatic planning and designing_Urban design parameters). Beograd: IP Zavet.

Radović, R. (2003). The form of the city. Novi Sad: Stylos Art.

Radović, R. (2005). New garden and the old cage, pg. no. 210. Novi Sad: Stylos Art. 
Santosa, G., \& Behrendt, B. (2010) Road transport externalities, economic policies and other instruments for sustainable road transport. Retrieved from http://dx.doi.org/10.1016/j.retrec.2010.03.002

Saarinen, E. (1972). Gradovi, njihov razvitak, njihovo propadanje, njihova budućnost (Cities, their development, their degradation, their future). Sarajevo: Svjetlost.

Shergold, I., \& Parkhurst, G. (2016). The economic benefits of sustainable urban mobility measures: Independent review of evidence: Report. Bristol: University of the West of England.

Swart, R., \& Raes, F. (2011). Making integration of adaptation and mitigation work: Mainstreaming into sustainable development policies. Pp. 288-303.

Wuppertal Institute for Climate, Environment and Energy in Cooperation With Contemporary Transport, Erasmus University Rotterdam, TAEM Urbanistai, University of the West of England, Urban Planning Institute of the Republic of Slovenia. (2014). How urban transport projects are appraised: Current practice in the EU. Retrieved from https://ec.europa.eu/energy/ intelligent/projects/en/projects/evidence 